\title{
Interpretation of Bouguer Anomaly Maps, Geothermal Gradient Data and Exploratory Wells Results - A Case Study of Dungunab Area in Red Sea Coast Region, Northeastern Sudan
}

\author{
Mohamed Elfatih Z. Gandol \\ Lecturer at Department of Petroleum Geology, Faculty of Petroleum and Minerals, Al Neelain University, Khartoum-12702, Sudan and PG \\ Scholar at Department of Geophysics, Centre of Exploration Geophysics, Osmania University, Hyderabad-500007, India
}

\begin{abstract}
The Sudanese Red Sea region have been surveyed and explored by AGIP Companey since 1965 and three wells have been drilled where no oil has been encountered. The general stratigraphic succession of Red Sea coastal plain is divided from the youngest to several Formations: Shagara (Pliocene-Pliestocene),Wardan, Zeit, Dungunab, Belayim, Hamamit and Mukawar (Upper Cretaceous) and including four major tectonic phases. The main objective of this study is to use the available gravity and geothermal gradient data in Dungunab area to delineating the sedimentary extension of the study area and surrounding coastal areas by use of gravity indicator. And to emphasize on the rifting effects on the Red Sea coastal area the gravity interpretations. In addition to make use of the temperature gradient data available for the area in assessing the hydrocarbon generation type. Bougure anomaly maps showed the extinction of the sediments along the coastal plain of the Red Sea region and also showed locations of major structures which may be related to tectonic rifting. Temperature gradient indicator gave a good potentiality of oil generation in Abu Shagara-1 and Mughersum1 wells where a sufficient thickness for entrance to oil zone has been encountered, but Dungunab-1 well area has no enough sedimentary thickness to produce oil. The correlation model from the well results indicated gas potentiality in the area between Abu Shagara-1 and Mughersum-1 well and the surroundings but Dungunab-1 well area and surrounding area have no any type of potentiality or hydrocarbon shows.
\end{abstract}

Keywords: Red Sea, Dungunab, Abu Shagara, Mughersum, Bougure, Geothermal, Correlation.

\section{Introduction}

Dungunab area is located in Red Sea State of northeastern Sudan (Figure 1). It lies about $167 \mathrm{Km}$ north of PortSudan town and it is bounded by Lat. $20^{\circ} 45^{\circ}-21^{\circ} 21^{\prime} \mathrm{N}$ and Long. $36^{\circ} 51^{\prime}-37^{\circ} 27^{`} \mathrm{E}$. it includes four major areas: Dungunab Bay, Abu Shagara peninsula, Mohammad Qol town and Mughersum Island as shows in figure 2. The area is accessible from Khartoum by two highways: KhartoumAtbara-Haya-PortSudan and Khartoum-Kassala-PortSudan, PortSudan served by an international airport. And then by asphaltic road to the study area. Dungunab area has distinctive topographically shape defined as Dungunab Gulf. The Red Sea hills extend as a continuous chain of high mountains running parallel to the coastline. Their altitude averages $3000 \mathrm{~m}$ above sea level with some higher and lower peaks. They show a steep eastern slope dissected by many khors and wadies. Sudan's $750 \mathrm{~km}$ long coastline and numerous uninhabited islands and offshore reefs are within the centre of marine diversity in the Red Sea. The Sudanese coastal plain represents almost flat, low-lying narrow zone with an approximate width of $16 \mathrm{~km}$. The temperature is high, with an average of 30 degrees Celsius. Records indicate mean annual rainfall in Red sea state to be in the range of 30 to $90 \mathrm{~mm}$ per annum (Babiker \& Pantuliano, 2006. Pantuliano, 2000). Neither the saline soils found on the coastal plain nor the rocky soils found in the hills hold much groundwater which means pastures and thus grazing opportunities are limited as are opportunities for cultivation (Babiker \& Pantuliano, 2006). Generally, the drainage pattern of the Red Sea Hills is structurally controlled. Faults and folds produce rectangular drainage pattern whereas large batholiths produce radial patterns (Harrison and Jackson, 1958).

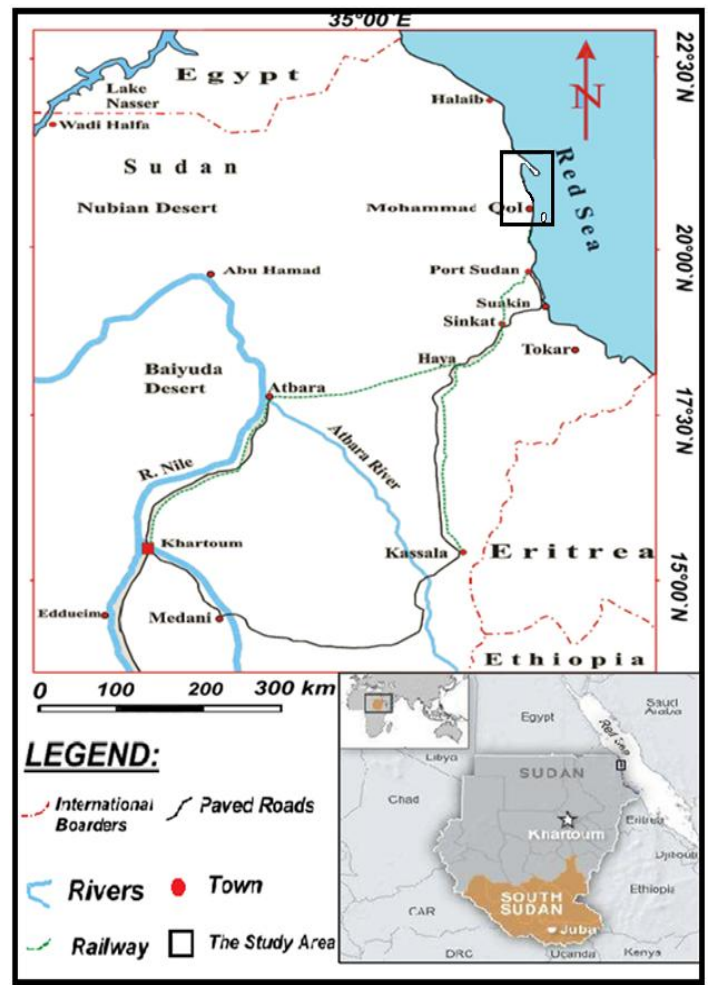

Figure 1: Location map of the study area (Modified after Mudather, 2007). 


\section{International Journal of Science and Research (IJSR) \\ ISSN (Online): 2319-7064}

Index Copernicus Value (2013): 6.14 | Impact Factor (2015): 6.391

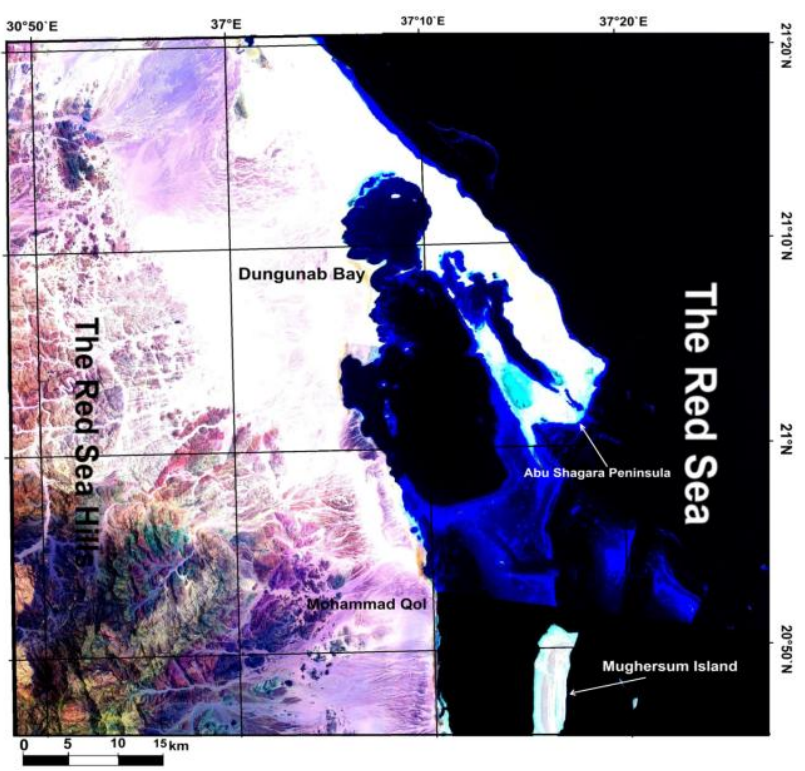

Figure 2: Color composite image of Landsat ETM7 prepared using bands 7, 4, 1 In RGB respectively for the study area.

Oil exploration activities in Sudan began exactly in 1959, when AGIP, an Italian Oil Company, was given an exploration concession in the Red Sea area of the northeast Sudan. However, No oil production found. According to RRI \& GRAS (1991) many international companies took out oil exploration licenses in the Red Sea costal area. The work they subsequently undertook ranged from surface geology to exploration drilling.

The purpose of the present work is to make use of the available gravity data to infer the extension of the sediments in the area and the major tectonic and structural controls and also to use geothermal gradient indicators for the thermally promising areas for the oil and gas generation.

\section{Geology and Tectonic Settings}

The Red Sea and the surrounding regions exposed to extensive research, which deals with the regional geology and tectonics of the area. The stratigraphic succession of the numerous igneous, sedimentary and metamorphic rocks that crop out in the Sudanese Red Sea region was summarized by several authors [Carella and Scarpa (1962), Sestini (1965), Bunter and Abdel Magid (1989) and Mitchell et al. (1992). Details of these successions have been given by RRI (1988). Figure 3 shows generalized geological map of the Red Sea region (Mitchell et al. 1992).

The first major stratigraphic unit includes all igneous and metamorphic rocks forming the Red Sea Hills is generally considered to be of Precambrian age (Sestini , 1965). In the southern part of the Red Sea Hills, Delany (1956) recognized older granites, which comprise varieties of weakly foliated syn- or late-tectonic batholithic emplacements and gneisses, most probably belonging to the amphibolite facies. Several formations from Late Cretaceous to Recent, have been recognized on the basis of fossil content, lithology, and field relations. These include Mukawar and Hamamit Formations, Mughersum Group, Belayim, Dongunab and Zeit formations, and Abu Shagara Group (Carella \& Scarpa (1962); RRI
(1988); Whitemant (1971); Bunter \& Abdel Magid, (1989)).

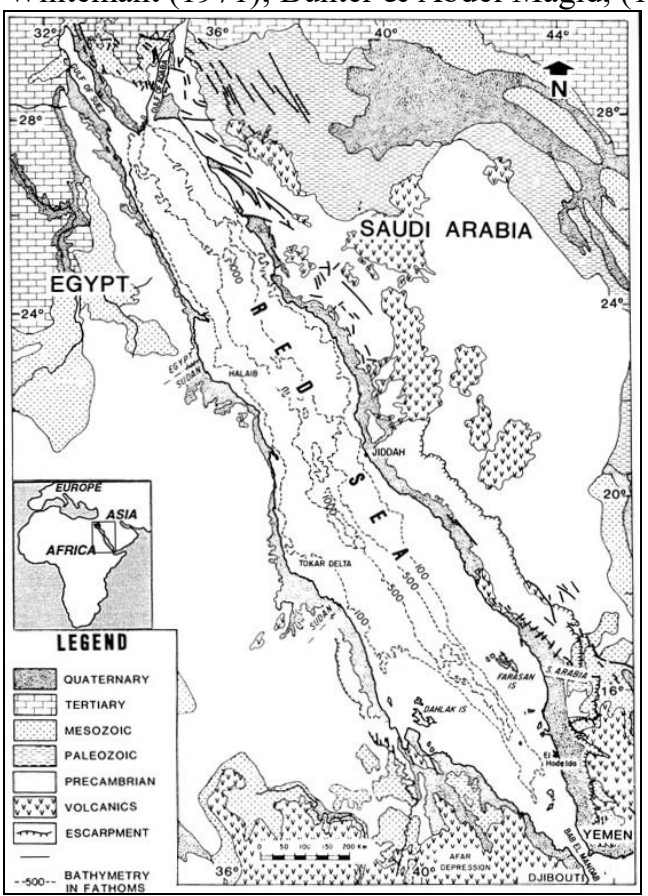

Figure 3: A map of the Red Sea region showing generalized geology (Mitchell et al. 1992).

During Early Paleozoic times, the Red Sea was located further from the Proto-Tethyan Ocean that it is at the present day from the Mediterranean Sea. The Cambrian paleogeography of the eastern part of Gondwana land shows that a rise in sea level at the end of Cambrian resulted in the deposition of marine and locally some continental Cambrian rocks onto the northern (Tetyan) marine of the African continent (Bunter and A/Magid, 1989). According to RRI (1984) there are four major rifting phases in the Red Sea region including; Pre-Rifting, Syn-Rift Pre-Salt, Salt Phase and Syn-Rift Post Salt phases.

\section{Methodology}

\subsection{Gravity Data}

Gravity data can be used to help define the regional tectonic regime, prioritize areas for seismic work, and identify the causes of seismic structure (Halliburton, 2001). Gravitational prospecting uses Newton's Law, which links the force of mutual attraction between particles in terms of their masses and separation. The law states that two particles of mass $\mathrm{m} 1$ and $\mathrm{m} 2$, and of small dimension compared with the distance $r$ that separates their centers of mass, will be attracted to one another by a force $\mathrm{F}$ as follows:

$$
F=G \frac{m_{1} m_{2}}{r^{2}}
$$

Where $\mathrm{G}$ is the universal gravitational constant which, in the centimeter-gram-second (c.g.s.) system, equals $6.670 \times 10^{8}$. The acceleration (a) of a mass $m 2$ due to the attraction of mass $m l$ at distance $r$ can be calculated by dividing the attractive force by the mass $m 2$ (since force is mass 2 acceleration), thus:

$$
a=\frac{F}{m_{2}}=G \frac{m_{1}}{r^{2}}
$$

\section{Volume 5 Issue 8, August 2016}




\section{International Journal of Science and Research (IJSR) \\ ISSN (Online): 2319-7064}

Index Copernicus Value (2013): 6.14 $\mid$ Impact Factor (2015): 6.391

In the c.g.s. system, acceleration is measured in units of $\mathrm{cms}^{2}$ . This unit is referred to as a "Gal" (after Galileo). The gravitational attraction at the Earth's surface is about 980 Gals. However, in exploration geophysics it is likely that measurement differences in acceleration of about one millionth of the Earth's field will be required. In consequence, the commonly used unit is the milliGal (where 1000 milli-GaIs=1 GaI).

Gravity anomalies are caused by the heterogeneous distribution of rocks of different density. Gravity data may be collected on land, at sea, or most commonly today by air. Gravity data are subject to a variety of corrections before they may be used for interpretation, including such as isostatic, tidal effects, temperature, latitude correction, free air correction and Bouguer correction. Bouguer maps are based on gravity data to which both the free-air and Bouguer correction have been applied. Such maps are commonly considered to represent "raw gravity." The information on them is used as the basis for separating anomalies by various analytical techniques.

Data were made available for the present study from the open file of the Ministry of the Energy and Mining, which includes Bouguer anomaly points with Interval $5 \mathrm{~km}$.Two Bouguer anomaly maps were prepared in the present work for the purpose of qualitative interpretation. All Bouguer anomaly maps and a three dimensional views have been prepared by Surfer9 software and have been used $5 \mathrm{mGal}$ as contour interval in the first map and $2 \mathrm{mGal}$ contour interval in the second map. And the corresponding location maps obtained by Google Earth software.

\subsection{Geothermal Gradient}

Temperature is a function of depth because of the earth's natural geothermal gradient. Normal heat flow within the earth's crust produces a gradient of approximately $1.5^{\circ} \mathrm{F}$ for each 100 feet of depth below the surface. There are, of course, exceptions to these rules. Geologic conditions such as volcanism and tectonics (folding and faulting) can change or affect the temperature gradient. The temperatures required to produce crude oil occur between 5,000 and 20,000 feet of depth. Temperatures below 20,000 feet are generally too high and only generate gas. Temperatures above 5,000 feet are not usually sufficient enough to transform the organic material into crude oil (Halliburton, 2001). Figure 4 represents the estimation of Formation Temperature in relation to depth (Schulumberger, 2000). The temperature gradient data for the study area were made available from ACRES (1992) which have been used to identify the thermal generation and potentiality of Dongunab-1, Abu Shagara-1 and Mugersum-1.

\subsection{The correlation Model of the Study wells}

The Correlation model of exploration wells has been prepared by Corel Draw X4 software by making use of some information such as wells coordinate, the distant between the wells, wells depth, stratigraphic Formations and wells results.

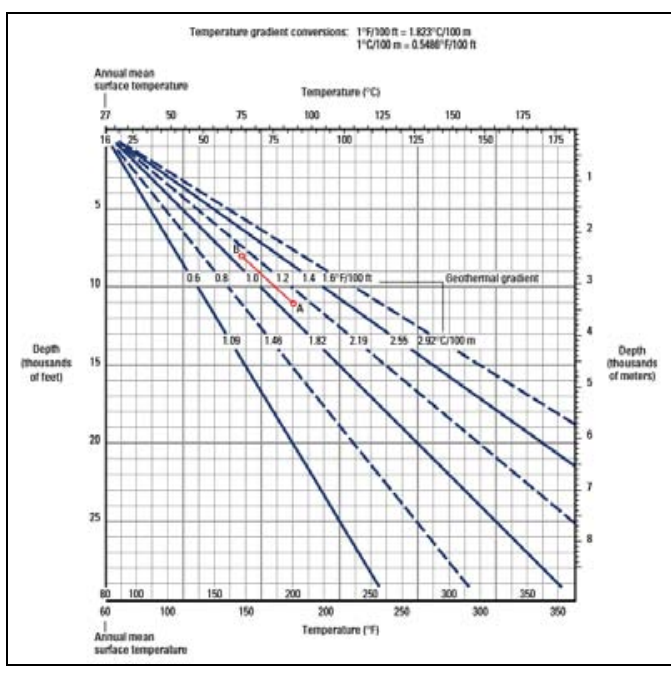

Figure 4: Estimation of Formation Temperature with Depth

(Schulumberger, 2000)

\section{Results and Discussion}

\subsection{Bouguer Anomaly Maps}

The first Bouguer anomaly map which has been prepared for the regional Sudanese coastal plain area is shown in Figure 6 the corresponding location map is represented in Figure 5 in addition, a three dimensional view as shown in Figure 7.

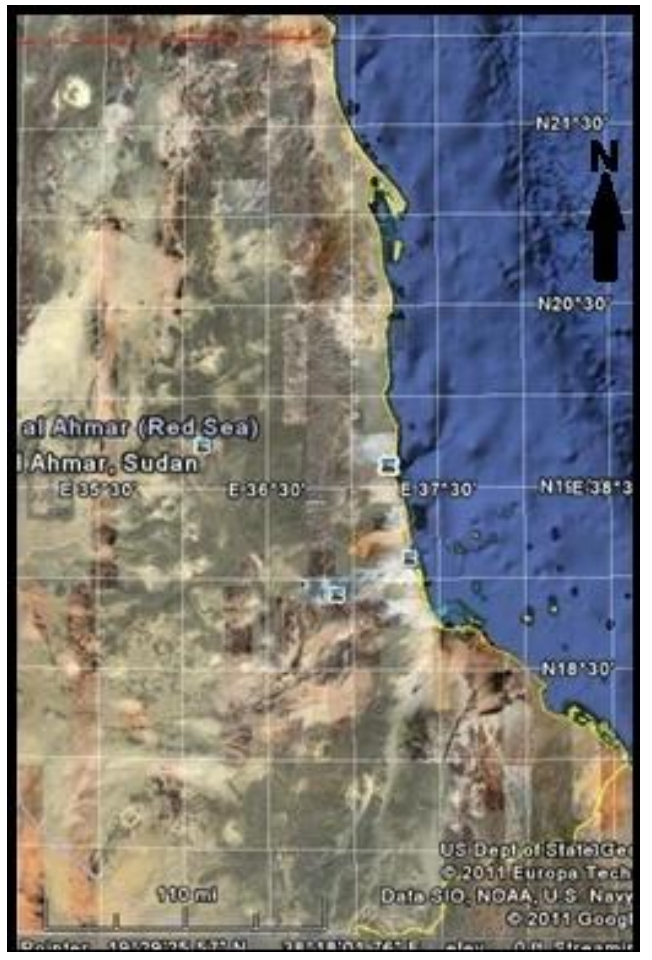

Figure 5: Location map of the regional Sudanese coastal plain area

The second Bouguer anomaly map (Figure 9) which was prepared in smaller scale for to meet the purpose of detail illustration of the study area and its corresponding location map is demonstrated in Figure 8 and the three dimensional view of the anomalies is shown in Figure 10.

The regional area bounded between latitudes $\left(17^{\circ} 00^{\prime}\right.$ $\left.21^{\circ} 99^{`} \mathrm{~N}\right)$ and longitudes $\left(35^{\circ} 00^{\prime}-37^{\circ} 99^{`} \mathrm{E}\right)$ and it has No. of 


\section{International Journal of Science and Research (IJSR) \\ ISSN (Online): 2319-7064}

Index Copernicus Value (2013): 6.14 | Impact Factor (2015): 6.391

7583 gravity points. And the study area falls between latitudes $\left(20^{\circ} 45^{\prime}-21^{\circ} 21^{\prime} \mathrm{N}\right)$ and longitudes $\left(36^{\circ} 51^{\prime}-37^{\circ} 27^{`} \mathrm{E}\right)$ it has a No. of 876 gravity points.

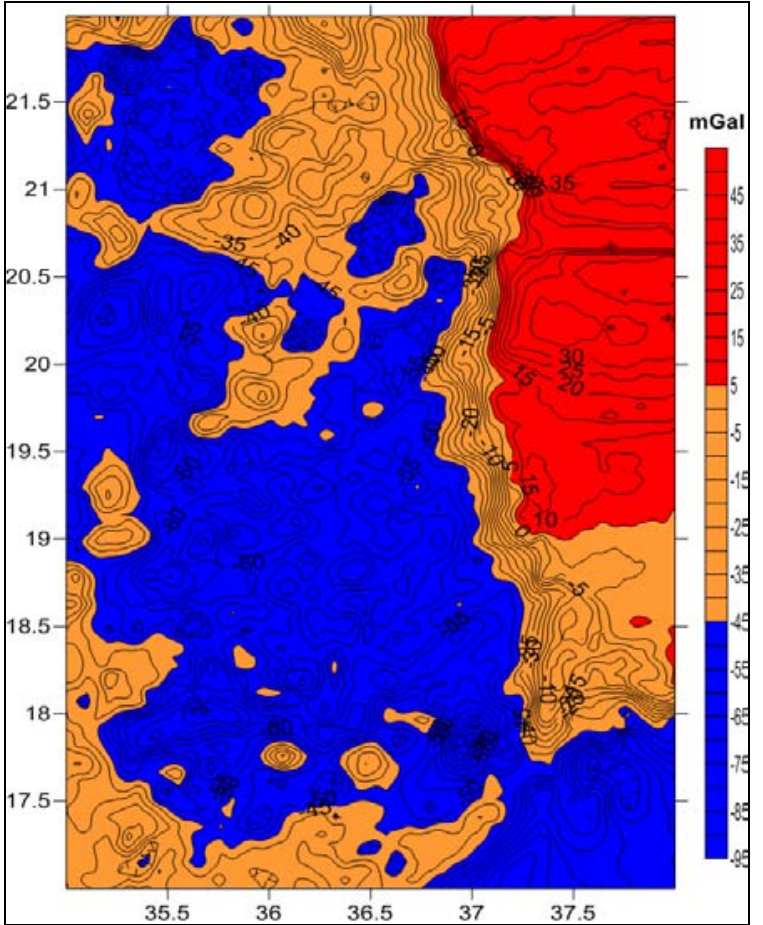

Figure 6: Bouguer anomaly map of the regional coastal plain

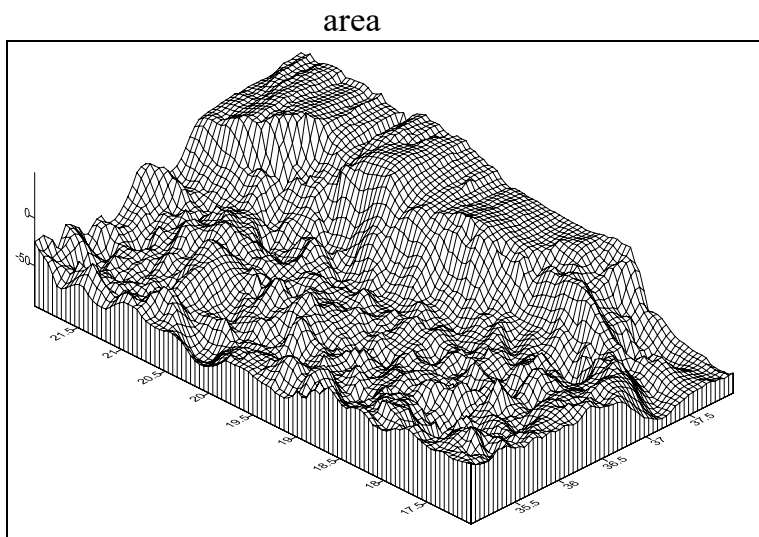

Figure 7: 3D view of the Bouguer anomaly map of the regional coastal plain area.

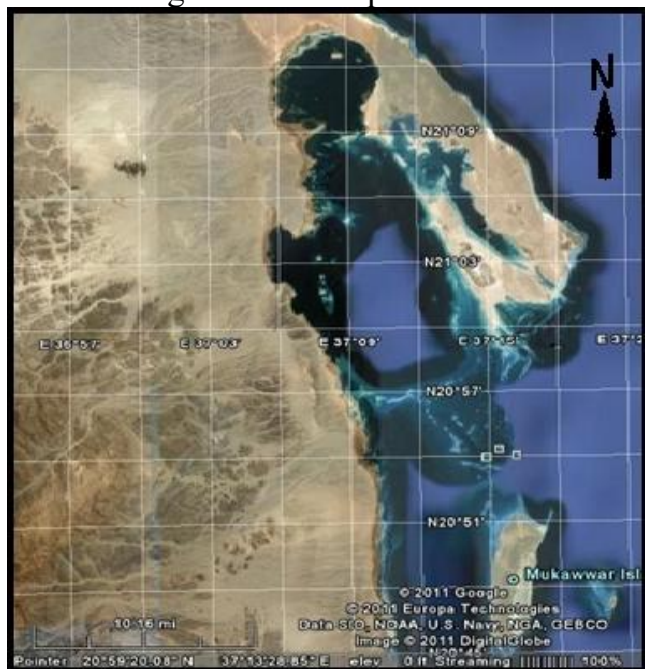

Figure 8: Location map correspondence of Bouguer anomaly map of the study area.

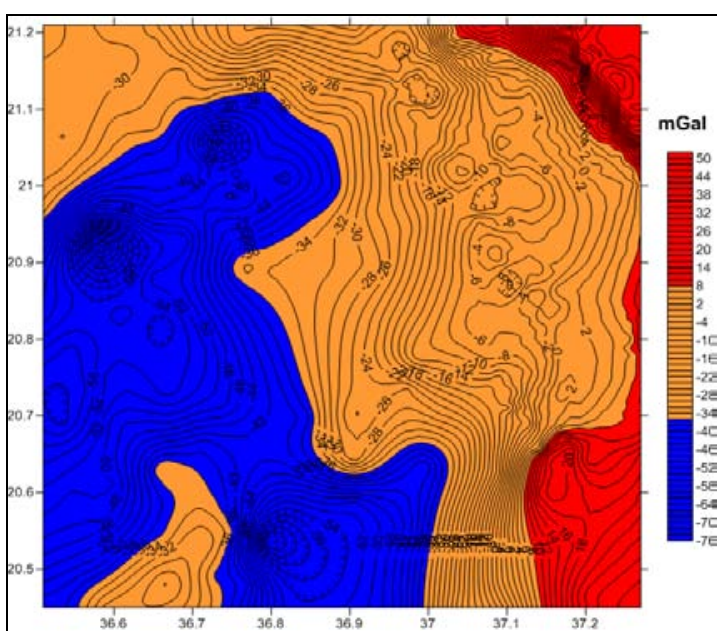

Figure 9: Bouguer anomaly map of the study area.

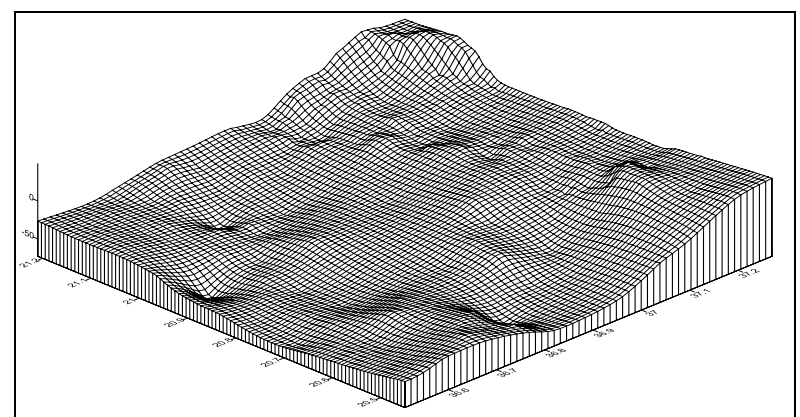

Figure 10: 3D view of the Bougueranomaly mapof the study area.

Figure 6 representing a regional Bouguer anomaly map (in larger scale) for the whole Sudanese coastal area, except Halaib area. The purpose of this map is identifying of the sedimentary extension along the coastal plain and showing the general trend of the regional structures. The anomaly values in this map range between $+55 \mathrm{mGal}$ (highest value) and $-95 \mathrm{mGal}$ (lowest value) as show in Figure 6 . The highly negative values (between +55 to $+5 \mathrm{mGal}$ ) plotted by red color in the map they are not represent basement area but this highly values refers to deep sea floor of the Red Sea. And the generally medium values (between +5 to $-45 \mathrm{mGal}$ orange colored area) it represents the extension of the coastal plain sediments. Whereas the highly negative values (between -45 to $-95 \mathrm{mGal}$ ) plotted by blue color are not represents low density area but it are basement areas and occurs of this lowest values refer to deep mantel under the mountains (i.e. deep Moho's line), this contrast between the three types of the values is apparent in $3 \mathrm{D}$ view in Figure 7 . The highly convergence of the contour lines in the interface between red and orange colored areas (eastern part of the map) indicating a fault in that area, this fault may be refer to the rifting of the Red Sea.

In the Bouguer Anomaly map of the study area (Figure 9) the values fall in range between $+50 \mathrm{mGal}$ to $-70 \mathrm{mGal}$ for the same reasons in the above interpretation, thus the blue colored areas are Red Sea hills and the orange colored areas area coastal plain sediment of the study area. The 3D view (Figure 10) is displaying the different between the anomaly values. The highly convergence of the contour lines in southeastern part of the map indicating a Fault in the area

Volume 5 Issue 8, August 2016 www.ijsr.net 


\section{International Journal of Science and Research (IJSR) \\ ISSN (Online): 2319-7064}

Index Copernicus Value (2013): 6.14 | Impact Factor (2015): 6.391

between latitudes $\left(20^{\circ} 4^{\prime}-20^{\circ} 65^{\prime} \mathrm{N}\right)$ and longitudes $\left(36^{\circ} 95^{`}\right.$ $\left.37^{\circ} 15^{`} \mathrm{E}\right)$, this Fault maybe related to the Rifting of the Red Sea. The same cases in the southwestern part of the map, where contour lines are converging that lead to expecting a fault in the basement area (blue colored area). When the geologic section contains successive formations having appreciable contrasts in density, any major folding should be reflected in the gravity map (Dobrin \& Savit, 1988), thus we expect three folds in the Basement area as in Figure 9 (blue colored area) but this expectation needs to be support by density information about the study area.

\subsection{Geothermal Gradient}

According to the ACRES (1992), the Temperature gradient values measured down to depths between 1500 and 2500 in the Dungunab-1, Abu Shagara-1 and Maghersum-1 wells, located in the Mohammed Qol area (Figure 11) about 140$180 \mathrm{~km}$ north of Port Sudan, the Temperature gradient values and wells coordinates are showing in table [5-1] as the following:

Table 1: Temperature gradient data for the exploration wells in the study area.

\begin{tabular}{|c|c|c|c|}
\hline Well & Dongunab-1 & Abu Shagara-1 & Mugersum-1 \\
\hline Latitude & $21^{\circ} .06^{\circ}$ & $21^{\circ} .03^{`}$ & $20^{\circ} .49^{`}$ \\
\hline Longitude & $37^{\circ} .05^{`}$ & $37^{\circ} .17^{`}$ & $37^{\circ} .17^{`}$ \\
\hline Depth (m) & $1500 \pm$ & $2500 \pm$ & $2500 \pm$ \\
\hline $\begin{array}{c}\text { Bottom Hole } \\
\text { Temperature }\left({ }^{\circ} \mathrm{C}\right)\end{array}$ & - & $95 \pm$ & $100 \pm$ \\
\hline $\begin{array}{c}\text { Temperature } \\
\text { Gradient }\left({ }^{\circ} \mathrm{C} / \mathrm{km}\right)\end{array}$ & 34.6 & 30.2 & 34.5 \\
\hline $\begin{array}{c}\text { Heat Flow } \\
(\mathrm{mWm} 2)\end{array}$ & 88.7 & 99.6 & 100.1 \\
\hline
\end{tabular}

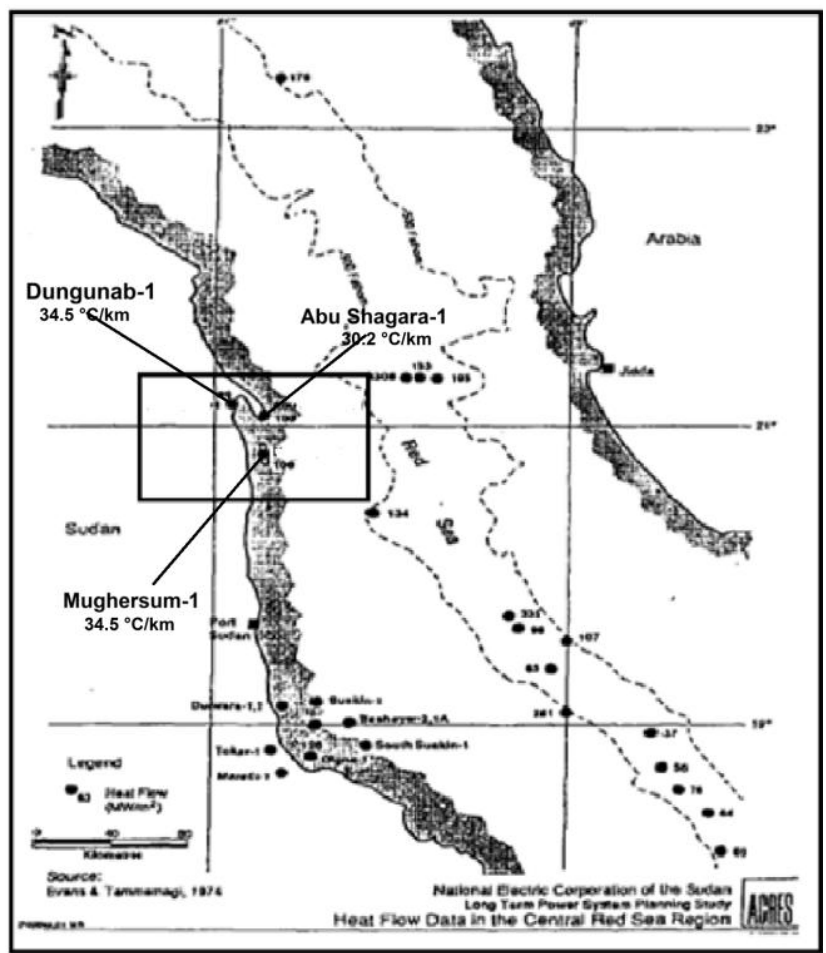

Figure 11: location of studied wells and their temperature gradient values (modified after ACRES, 1992).

In Dungunab-1 well the plotted temperature data in Pusey Diagram (Pusey, 1973) is shown in Figure 12. The result of the plot indicated that there are not enough sedimentary thicknesses for the entrance to the Oil and Gas zones. That was inferred because the basement was encountered below $1570 \mathrm{~m}$ depth in Dungunab-1 well. Figure 13 shows the plot of temperature gradient data of Abu Shagara-1 well in Pusey diagram. The diagram indicates the existence of enough sedimentary thickness for the entrance to the Oil generation zone $\left(65^{\circ} \mathrm{C}-150^{\circ} \mathrm{C}\right)$, this indicator is useful to shed some light on the promising well such as Abu Shagara-1 well. The temperature gradient data of Mughersum-1 which plotted in Figure 14 shows a sufficient thicknesses for entrance to the Oil generation zone based on Pusey diagram. Mughersum-1 as well as Abu Shagara-1 wells both have a good temperature gradient indicators adequate for Oil generated. Therefore, if suitable source rocks are found so oil will be highly expected in these wells.

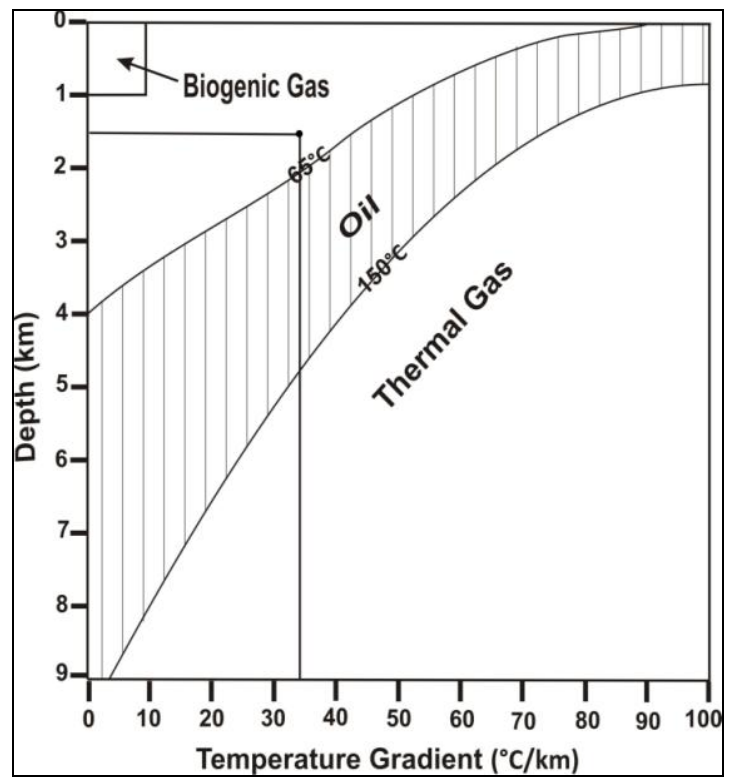

Figure 12: Pusey diagram showing temperature gradient indicator in Dungunab-1 well.

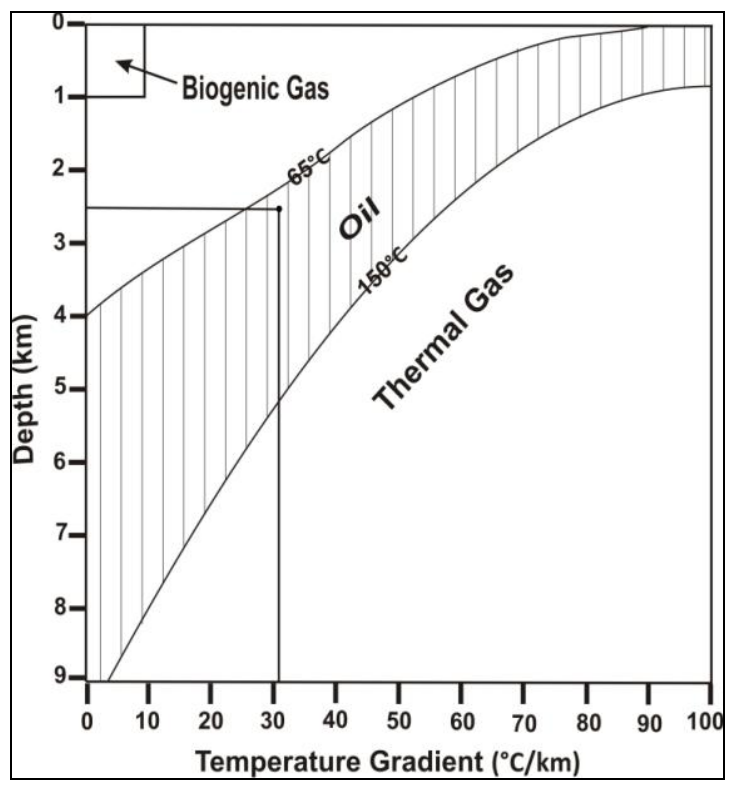

Figure 13: Pusey diagram showing temperature gradient indicator in Abu Shagara-1 well.

\section{Volume 5 Issue 8, August 2016} www.ijsr.net 


\section{International Journal of Science and Research (IJSR)}

ISSN (Online): 2319-7064

Index Copernicus Value (2013): 6.14 $\mid$ Impact Factor (2015): 6.391

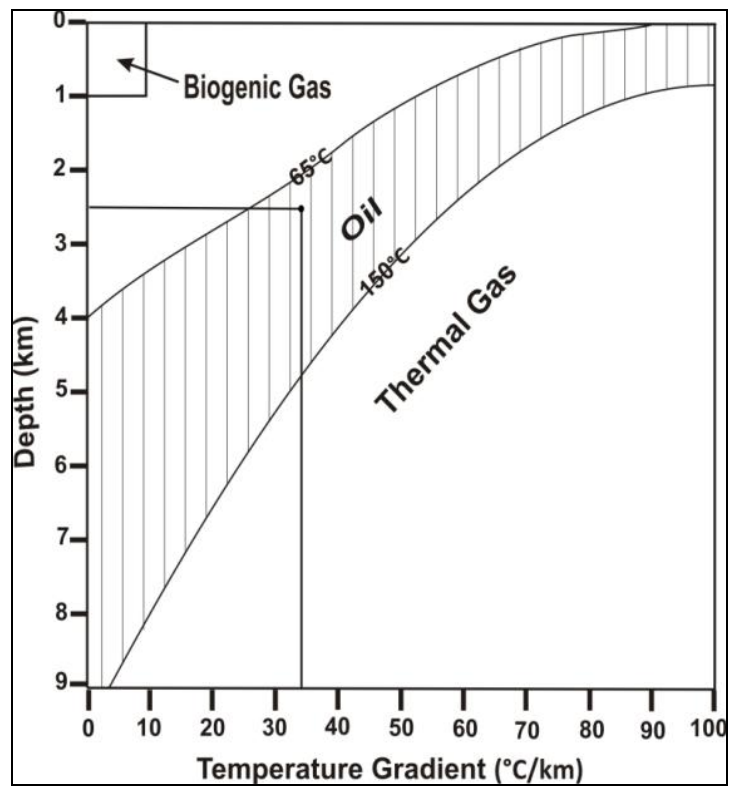

Figure 14: Pusey diagram showing temperature gradient indicator in Mughersum-1 well.

\subsection{The Correlation Model}

The results of Abu Shagara-1 well indicating the existence of dry gas-shows in Kareem and Radies Formation between $686 \mathrm{~m}-1666 \mathrm{~m}$ depth, and mainly Methane \& Ethane shows in Hamamit Formation between 1666m-2659m depth and there are not any Formations absent. Results of Dungunab-1 well did not give any oil or gas-shows with disappear of Shagara, Zeit, Radies and Mukawar Formations. Mughersum-1 well gave Methane, Ethane, Propane and Butane in Hamamit Formation whereas Kareem and Radies Formations are absent in Mughersum-1 well.

The correlation model (Figure 15) helped in defining a potentiality for gas in the area between Abu Shagara-1 and Mughersum-1 well and the surrounding area, but Dungunab1 well area and surrounding areas have no any type of potentiality or hydrocarbon shows. The dry gas shows founded in Abu Shagara-1 well in Kareem and Rudies Formations as plotted in yellow color, whereas the Methane, Ethane, Propane and Butane are founded in Abu Shagara-1 and Mughersum-1 wells in particularly Hamamit Formation.

\section{Conclusion}

Dundunab area northeastern Sudan has been conducted. The main purposes of the present work were to identify the sedimentary basin boundaries and the tectonic and structure control, to identify the oil and gas potentiality of the area and to tie it with the actual wells results. Bougure anomaly maps identified the extinction of the sedimentary basin along the coastal plain in addition to the locations of major faults which belong to rifting process. The geothermal gradient data gave a good indicator for oil generation in Abu Shagara-1 and Mughersum-1 wells but Dungunab-1 well area has no sufficient sedimentary thickness for oil generation. The correlation model prepared from the drilled wells results showed that the area between Abu Shagara-1 and Mughersum-1 well and the nearby surrounding area have gas potentiality but the area of Dungunab-1 well and the surroundings are not promising areas.

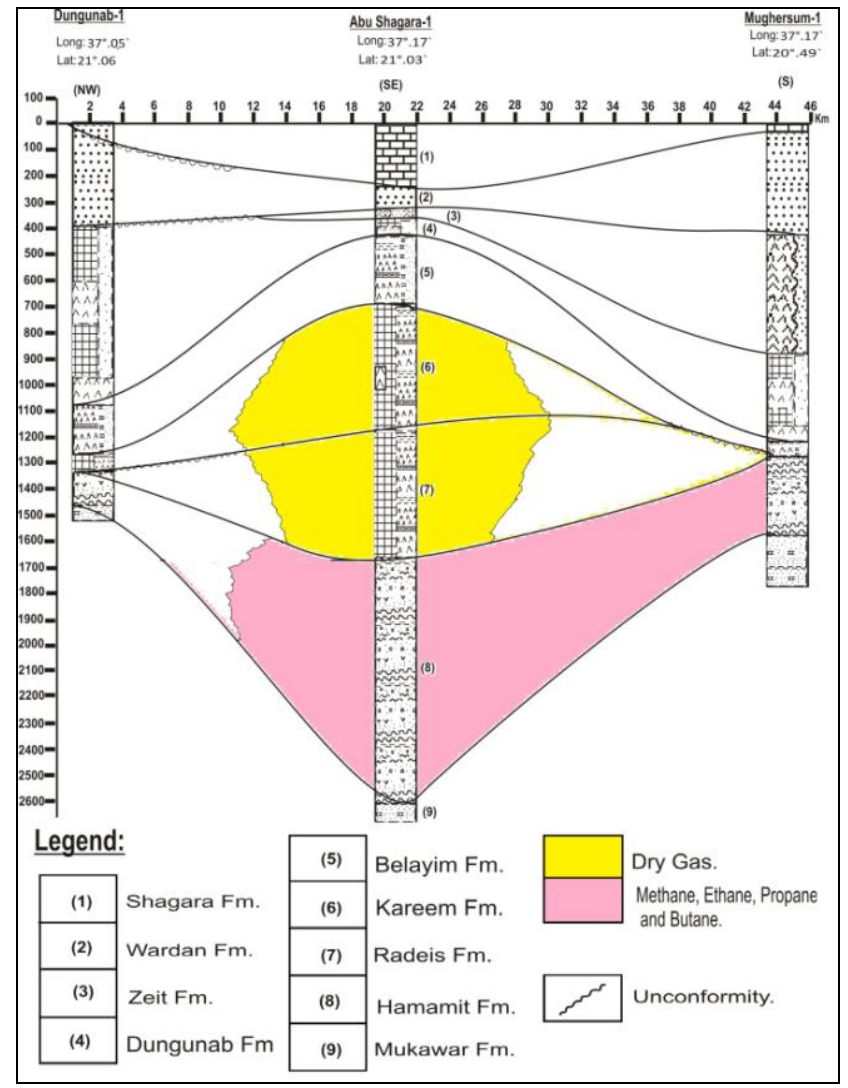

Figure 15: The Correlation Model of the exploration wells in the study area.

\section{Acknowledgment}

Special thanks go to Petroleum Geology Department, Faculty and Petroleum and Minerals of Al Neelain University in Sudan for providing the data and facilities.

\section{References}

[1] ACRES International Limited, 1992. Interim Report. Long Term Power System Planning Study. Heat Flow Data in the Central Red Sea Region. Unpublished report.

[2] Bunter, M \& A. E. M. Abdel Magid, 1989. The Sudanese Red Sea, new developments in stratigraphy and petroleum geological evolution. Journal of Petroleum Geology.

[3] Babiker, M. and S. Pantuliano (2006) Addressing Chronic Livelihoods Vulnerability in Red Sea State, Sudan. Commissioned report. Humanitarian Policy Group. London, Overseas Development Institute, Oxfam GB.

[4] Carella, R and Scarpa, N., 1962. Geological results of exploration in sudanby Agip Mineraria. Proc. 4th Arab Pet., 27 (B3) Beirut, 23P.

[5] Delany, F.M., 1956, Geological Map of Derudeib 46-J, scale 1:250,000: Geol. Surv. Sudan.

[6] Halliburton, 2001, Basic Petroleum Geology and Log Analysis, $73 \mathrm{pp}$. 
[7] Harrison, M. N. and J. K. Jackson (1958). Ecological classification of the Vegetation of the Sudan. Forest Bull. No 2. (New series) Forest Dept. Khartoum.

[8] J.Sestini, 1965. Cenozoic stratigraphy and depositional history of the Red Sea coast,Sudan.AAPG Bull.,49,9,1453-1472.

[9] Milton B. Dobrin and Carl H. Savit, 1988. Introduction To geophysical Prospecting-Fourth Edition, McgrawHill Book Company New York, 882pp.

[10] Mitchell, D.J.W., Allen, R.B., Salama, W., and Abouzakm, A., 1992, Tectonostratigraphic framework and hydrocarbon potential of the Red Sea: Journal of Petroleum Geology, v. 15, no. 2, p. 187-210.

[11] Mudather A. M. Osman, 2007, Facies Associations and Depositional Environments of the Miocene and Pleistocene Sedimentary Successions in Eit Area, Red Sea Coastal Plain, Sudan. PhD Thesis, Al Neelain University.

[12] Pantuliano, S. (2000) Changing Livelihoods: Urban Adaptation of the Beja Pastoralists of the Halaib Province (NE Sudan) and NGO Planning Approaches. $\mathrm{PhD}$ Thesis, University of Leeds.

[13] Pusey, III, W.D., 1973. How to evaluate potential gas and oil source rocks. World Oil, 176: 7 1-75.

[14] Robertson Research International Limited (RRI), 1984 and 1986. The Geology and Petroleum Potential of the Sudanese Red Sea. Petroleum Exploration promotion Study. Unpublished reports.

[15] Robertson Research International (RRI) \& the Geological Research Authority of Sudan (GRAS), 1991, the geology and petroleum potential of southern, central and eastern Sudan. Volumes 1- 4 (unpublished reports).

[16] Schulumberger (2000), Petrophysics Interpretation. Retrieved July 31, 2016. [Online]. Available: http://petrophysicsinterpretation.blogspot.in/2010/03/gen-2.html

[17] Whiteman, A. J. 1971. The geology of Sudan Republic. Clarendon Press, Oxford, 290 pp.

\section{Author Profile}

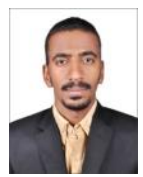

Mohamed Elfatih Z. Gandol is a lecturer at Petroleum Geology department of Al Neelain University in Khartoum, Sudan. In 2011 he completed B.Sc. (Honours) in Petroleum Geology at the same University. In 2012 he joined Chinese National Logging Corporation (CNLC) as Mudlogging Geologist and in the same year he moved to Spanish Sudanese (SPSU) Mining Company as Senior Exploration Geologist. In 2013 he joined Al Neelain University as Teaching Assistant, in 2014 he received his M.Sc. in Petroleum Geochemistry from it and promoted to his present position. Currently he is doing M.Sc. course in Geophysics at Osmania University, Hyderabad, India. 